\title{
EVALUASI PELAKSANAAN BASIC HOUSEKEEPING PADA RUANG RAWAT INAP RUMAH SAKIT PKU MUHAMMADIYAH GOMBONGTAHUN 2017
}

\author{
Nur Hikmawati*), Tri Cahyono ${ }^{* *}$ \\ Jurusan Kesehatan Lingkungan, Politeknik Kesehatan Kemenkes Semarang, \\ Jl.Raya Baturaden KM 12 Purwokerto, Indonesia
}

\begin{abstract}
Abstrak
Pemeriksaan angka kuman pada lantai ruang Barokah Mei 2016 sebesar 58 CFU/ $\mathrm{cm}^{2}$ dan toilet ruang Barokah bau.Hasil pemeriksaan angka kuman pada handle pintu kamar observasi pada ruang rawat inap Barokah sebesar $19 \mathrm{CFU} / \mathrm{cm}^{2}$, pada lantai ruang rawat inap Inayah kamar nomor 21 sebesar 31 $\mathrm{CFU} / \mathrm{cm}^{2}$. Pelaksanaan dusting sudah sesuai dengan SOP, namun pelaksanaan dusting pada handle pintu tidak dilakukan padasetiapshift. Pelaksanaan dry mopping dengan lobby duster di ruang Inayah sudah sesuai dengan SOP, di ruang Barokah menggunakan nylon broom. Pelaksanaan damp mopping dengan kentucky mop belum sesuai dengan SOP karena petugas tidak memasang warning sign. Pelaksanaan glass cleaning pada ruang Inayah dan Barokah tidak dilakukan secara rutin. Pelaksanaan toilet cleaning belum sesuai dengan SOP , karena petugas membiarkan chemical kurang dari lima menit. Kesimpulan penelitian adalah pelaksanaan basic housekeeping yangsudahdilaksanakansesuaidengan standar operational procedure yaitu : dusting, drymopping denganlobby duster danglasscleaning.
\end{abstract}

Kata kunci:basic housekeeping;rumah sakit; kesehatan lingkungan

\begin{abstract}
Evaluation of Basic Housekeeping Performance on Patient's Room in PKU Muhammadiyah Hospital Gombong Year of 2017. The investigation of Barokah's floor room bacteria in May 2016 was 58 $\mathrm{CFU} / \mathrm{cm}^{2}$, the toilet was smell bad. The research result shows that the Barokah door's handle bacteria's number was $19 \mathrm{CFU} / \mathrm{cm}^{2}$, Inayah patient room number 21, the floor bacteria's number was $31 \mathrm{CFU} / \mathrm{cm}^{2}$. The dusting was conducted according to SOP, however the door's handle dusting was not conducted. The dry mopping using lobby duster in Inayah's room already conducted according to SOP, in Barokah's room using nylon broom. Damp mopping using kentucky mop was not conducted according to SOP because the employee did not put the warnig sign. The glass cleaning in Inayah's and Barokah's room was not regularly conducted. The toilet cleaning was conducted according to SOP, because the employee let the chemical sit less than 5 minutes. The research conclusion drawn was basic housekeeping that conducted according to standard operational procedure was : dusting, dry mopping with lobby duster and glass cleaning.
\end{abstract}

Keywords:basic housekeeping; hospital; environmenthal health

\section{Pendahuluan}

Berdasarkan UU RI Nomor 36 tahun 2009 tentang Kesehatan, Kesehatan merupakan keadaan sehat, baik secara fisik, mental, spritual maupun sosial yang memungkinkan setiap orang untuk hidup produktif secara sosial dan ekonomis.PP No. 66 tahun 2014

\footnotetext{
${ }^{*}$ E-mail: nurhikma697@gmail.com

${ }^{* *}$ E-mail: tricahyono37@yahoo.co.id
}

tentang Kesehatan Lingkungan, Standar baku mutu kesehatan lingkungan dan persyaratan kesehatan ditetapkan pada media lingkungan yang meliputi : air, udara, tanah, pangan, sarana dan bangunan, vektor dan binatang pembawa penyakit. Penyehatan sarana dan bangunan meliputi upaya pengawasan, perlindungan dan peningkatan kualitas sanitasi sarana dan bangunan. Infeksi nosokomial merupakan infeksi yang diperoleh selama dalam perawatan di rumah sakit (MichaelJ.Pelzar,Jr., dan E.C.S. CHAN, 2008, h.732). Faktor - faktor penyebab terjadinya infeksi nosokomial 
meliputi :manusia, agent, lingkungan dan alat sarana prasarana. Alat sarana prasarana meliputi alat medis dan penunjang medis, seperti : tempat tidur, kursi roda dan kamar pasien. Pengendalian infeksi nosokomial dengan cara desinfeksi dan sterilisasi di rumah sakit, Pengawasan penderita,Pengawasan pekerja dan pengawasan lingkungan rumah sakit.Hasil penelitian Ratna Nugraheni, Suhartono dan Sri Winarni menunjukkan prevalensi angka kejadian infeksi nosokomial di RSUD Setjonegoro Kabupaten Wonosobo pada semester II tahun $2009(2,67)$, semester I dan II tahun 2010 ( 3,12 dan 4,36 ), serta semester I dan II tahun 2011 ( 9,68 dan 19,71 ) per 1000 pasien rawat inap. Proporsi kejadian infeksi nosokomial terbanyak menurut ruang, pada tahun 2009 di ruang Edelweis sebesar 47,36\%, pada tahun 2010 di ruang Bougenville sebesar 65,3\% dan pada tahun 2011 di ruang Anggrek sebesar 19,47\%.. Tujuan umum penelitian iniyaitu mengevaluasi pelaksanaan basic housekeeping pada ruang rawat inap Inayah dan Barokah.Menurut hasil penelitian Indah Rakhmi Pafitri(2016) menunjukkan rata - rata angka kuman pada handle pintu ruang kamar 6 sebesar $1.632,5 \mathrm{kol} / \mathrm{cm}^{2}$, Ruang kamar 7 sebesar $900 \mathrm{kol} / \mathrm{cm}^{2}$, Ruang kamar 8 sebesar 632,5 kol/ $\mathrm{cm}^{2}$, Ruang isolasi 2 sebesar 550 $\mathrm{kol} / \mathrm{cm}^{2}$, Ruang isolasi 3 sebesar $647,5 \mathrm{kol} / \mathrm{cm}^{2}$.Sehingga didapatkan rata - rata $872,5 \mathrm{kol} / \mathrm{cm}^{2}$. Hasil penelitian Tria Widiastuti(2008)rata - rata angka kuman lantai ruang perawatan bangsal anak kelas III Rumah Sakit Umum Daerah Brebes sebelum pemberian desinfektan adalah29,88koloni $/ \mathrm{cm}^{2}$. Hal ini menunjukan bahwa lantai di ruang perawatan bangsal anak kelas III belum memenuhi standar dengan standar yang disyaratkan yaitu 5 - $10 \mathrm{koloni} / \mathrm{cm}^{2}$ untuk ruang perawatan.Rumah Sakit PKU Muhammadiyah Gombong merupakan Rumah Sakit Swasta Madya Type C. Rumah sakit ini mampu memberikan pelayanan kedokteran spesialis terbatas dan menampung pelayanan rujukan dari Puskesmas.di Rumah Sakit PKU Muhammadiyah Gombong terdapat 136 tempat tidur inap dengan BOR ( Bed Occupancy Rate/prosentase penggunaan tempat tidur ) 66,57 \%, BOR menggambarkan tinggi rendahnya tingkat pemanfaatan tempat tidur rumah sakit.Menurut hasil pemeriksaan pada Mei 2016 oleh Laboratorium Kesehatan Daerah Kebumen didapatkan hasil angka kuman lantai di ruang Husna $47 \mathrm{CFU} / \mathrm{cm}^{2}$, Barokah 58 $\mathrm{CFU} / \mathrm{cm}^{2}$ dan Rahmah $56 \mathrm{CFU} / \mathrm{cm}^{2}$.termasuk tidak memenuhi syarat menurut Kepmenkes RI No.1204/Menkes/SK/X/2004 tentang Persyaratan Kesehatan Lingkungan Rumah Sakit yaitu untuk lantai harus bersih dengan tingkat kebersihan ruang perawatan 5 - $10 \mathrm{CFU} / \mathrm{cm}^{2}$. Hasil pemeriksaan angka kuman pada AC ruang Isolasi Inayah pada Oktober 2016 sebesar 26 $\mathrm{CFU} / \mathrm{cm}^{2}$, Angka kuman maksimal pada AC yang diperbolehkan sebesar $0 \mathrm{CFU} / \mathrm{cm}^{2}$, yang berarti bahwa AC pada ruang Isolasi Inayah tidak memenuhi baku mutu. Berdasarkan survei pendahuluan yang telah peneliti lakukan, Terdapat pintu yang rusak pada toilet di ruang rawat inap Inayah dan terdapat toilet yang berbau pada ruang rawat inap Barokah. Rumusan masalah dalam penelitian ini yaitu Bagaimana pelaksanaan basic housekeeping pada ruang rawat inap Rumah Sakit PKU Muhammadiyah Gombong tahun 2017. Tujuan khusus penelitian ini adalah mengevaluasi pelaksanaan dusting, mengevaluasi pelaksanaan dry mopping dengan lobby duster, mengevaluasi pelaksanaan damp mopping dengan kentuky mop, mengevaluasi pelaksanaan glass cleaning, mengevaluasi pelaksanaan toilet cleaning, mengevaluasi pelaksanaan scrubbing, mengevaluasi pelaksanaan wet vacuuming, mengevaluasi pelaksanaan dry vacuuming, mengevaluasi pelaksanaan stripping lantai vynl, mengevaluasi pelaksanaan coating lantai vynil.

\section{Bahan dan Metode}

Komponen penyusun penelitian ini yaitu input yang meliputi : ruang rawat inap, tenaga basic housekeeping, alat dan bahan bassic housekeeping dan SOP pelaksanaan basic housekeeping. Proses kegiatan Basic Housekeeping di ruang rawat inap, meliputi Dusting, Dry Mopping dengan Lobby Duster, Damp Moppingdengan Kentucky Mop, Glass Cleaning, Toilet Cleaning, Scrubbing, Wet Vacuuming, Dry Vacuuming, Stripping lantai Vynil, Coating lantai Vynil.Outputnya dibandingkan dengan menggunakan standard performance of area : hospitalyang meliputi pada ruang kamar yaitu lantai harus : selalu bersih dan kering, bebas dari sampah, tidak berdebu, mengkilap. sudut lantai bersih tidak berdebu dan bernoda. Dinding yaitu, tidak ada noda, assesoris bersih, tidak berdebu dan bernoda, kaca bersih, mengkilap dan tidak bernoda. Padalangit langit yaitu, bersih, tidak ada noda, ac atau exhaust grill, reflector lampu bersih, tidak ada sarang laba - laba, tidak berdebu dan bernoda, ditata dengan rapi. Langit langit yaitu, bersih, tidak ada noda, ac atau exhaust grill, reflector lampu bersih, tidak ada sarang laba - laba, tidak berdebu dan bernoda, ditata dengan rapi.Bed yaitu, rangka bed tidak berdebu / bernoda.Lantai toilet : Kering, tidak berdebu dan tidak lengket, Lantai disekitar Bowl bersih, Lantai dibawah Wash Basin bersih, Lantai dibawah keset bersih dan kering, Lantai tidak bernoda, bebas dari sampah, Sudut lantai bersih dan tidak berlumut, Floor Drain tidak berlendir dan tidak bau. Dinding toilet : Bersih dan kering, Tidak bau, Lubang toilet bowl bebas dari kerak air, Flusher bersih dan mengkilap. Wash Basin :Bersih, kering, tidak bernoda, Kran dan drain mengkilap, Tidak berlendir dan tidak berkerak, Shower curtain bersih, kering, tidak bernoda.Waste basin :Unit dilap bagian luar dan dalam, Bersih tidak bernoda, bebas sampah.Jenis penelitian yang digunakan adalah penelitian Observasional menggunakan analisis deskriptif dengan pendekatan 
cross sectional karena penelitian ini hanya dilakukan secara sesaat.Lokasi penelitian dilakukan di ruang rawat inap Inayah dan Barokah Rumah Sakit PKU Muhammadiyah Gombong yang berlokasi di Jalan Yos Sudarso 461 Gombong Kebumen, Jawa Tengah.Ruang lingkup materi dalam penelitian ini adalah bidang kesehatan lingkungan dengan spesifikasi sarana prasarana pada pelaksanaan Basic Housekeeping, yang meliputi Dusting, Dry Mooping dengan Lobby Duster, Damp Mopping dengan Kentucky Mop, Glass Cleaning, Toilet Cleaning, Wet Vacuuming, Dry Vacuuming, Scrubbing, Stripping lantai Vynil, Coating lantai Vynil. Untuk menjaga kebersihan ruang rawat inap yang ada di Rumah Sakit PKU Muhammadiyah Gombong.Subyek penelitian ini adalah ruang rawat inap kelas tiga yaitu Inayah dan ruang rawat inap untuk masyarakat yang menggunakan kartu Jaminan Kesehatan Masyarakat yaitu Barokah. Jenis data dalam penelitian ini yaitu data umum yang meliputi : Meliputi gambaran umum RS PKU Muhammadiyah Gombong, ruang Inayah dan Barokah, jumlah pasien, dan jumlah pengunjung.Data khusus dalam penelitian ini meliputi, kriteria pelaksanaan basic housekeeping meliputi : Dusting, Dry Mooping dengan Lobby Duster, Damp Mopping dengan Kentucky Mop, Glass Cleaning, Toilet Cleaning, Wet Vacuuming, Dry Vacuuming,Scrubbing, Stripping lantai Vynil, Cooating lantai Vynil.Sumber data penelitian ini yaitu Sumber data primer dalam penelitian ini adalah kegiatan pengamatan di ruang rawat inap Inayah dan Barokah Rumah Sakit PKU Muhammadiyah Gombong terhadap pelaksanaan Basic Housekeeping yang dilakukan oleh ISS.Sumber data sekunder dalam penelitian ini buku - buku acuan atau referensi serta arsip dokumen rumah sakit.Cara pengumpulan data dengan cara : studi dokumendengan mengutip data dari arsip dan laporan rumah sakit sesuai kebutuhan peneliti, observasiterhadap obyek yang diteliti yaitu pengamatan pelaksanaan Basic Housekeeping yang meliputi : Dusting, Dry Mooping dengan Lobby Duster, Damp Mopping dengan Kentucky Mop, Glass Cleaning, Toilet Cleaning, Wet Vacuuming, Dry Vacuuming, Scrubbing, Stripping lantai Vynil, Cooating lantai Vynil di ruang rawat inap., wawancaradengan pasien, pengunjung dan petugas kebersihan di rumah sakityaitu mengadakan pemeriksaan laboratorium dengan usap lantai dan usap dinding, cara kerja terlampir. dan pemeriksaan. Instrumen pengumpul data dalam penelitian ini yaitu Ceklist yaitu daftar pertanyaan yang diisi oleh peneliti dengan mengobservasi tempat penelitian, Kuesioneryaitudaftar pertanyaan yang ditujukan kepada responden dengan wawancara, Seperangkat alat pemeriksaan angka kuman pada lantai, handle pintu dan AC.Analisis data dalam penelitian adalah dengan mendeskripsikan data dalam bentuk tabel dan narasi.Berdasarkan standar performance of area hospital dan Kepmenkes RI
No.1204/Menkes/SK/X/2004 tentang Persyaratan Kesehatan Lingkungan Rumah Sakit.

\section{Hasil dan Pembahasan}

Rumah sakit PKU Muhammadiyah Gombong, Kebumen terletak di Jalan Yos Sudarso nomor 461 Gombong, Kebumen. RS PKU Muhammadiyah Gombong memiliki batas bagian sebelah utara dengan Jl. Yos Sudarso, sebelah timur dengan Pemukiman Penduduk, sebelah barat dengan Pemukiman penduduk dan sebelahselatan dengan persawahan penduduk.Rumah Sakit PKU Muhammadiyah Gombong merupakan rumah sakit tipe $\mathrm{C}$ dengan pelayanan pasien 24 jam dengan jenis pelayanan rawat inap, rawat jalan, fasilitas pelayanan umum ( Masjid, ATM, Waserda ), billing system, pemulasaran jenazah, home care, ambulan gawat darurat dan telah melakukan MOU pelayanan dengan pihak ketiga sebagai penjamin pelayanan kesehatan yaitu: PT. Askes, Jamkesmas, Jamsostek, Jasa raharja, Asuransi Tafakul, DSM, PT. KAI, Allianz, PLN dan Telkom. Pendirian Rumah Sakit Umum PKU Muhammadiyah Gombong berawal pada 26 April 1958, berdiri sebagai Balai Pengobatan Muhammadiyah Gombong sesuai dengan ijin Bupati Kebumen No.5/ 57/ DPD/ Kes/ 1958 dan kemudian pada tahun 1967, dikembangkan menjadi balai pengobatan atau rumah bersalin dan mendapat pengakuan sebagai klinik KB Swasta pertama di Kabupaten Kebumen, Selanjutnya pada tahun 2012 lulus akreditasi 16 pelayanan dan mendapatkan sertifikat ijin pelayanan kelas rumah sakit tipe C.Jenis tenaga kerja di RS PKU Muhammadiyah Gombong adalah tenaga kerja pegawai kontrak dan pegawai tetap. Jumlah tenaga kerja di RS PKU Muhammadiyah Gombong adalah sebagai berikut :

Tabel 1. Jumlah dan Jenis Tenaga Kerja

\begin{tabular}{clr}
\hline No & \multicolumn{1}{c}{ Jenis Tenaga Kerja } & Jumlah \\
\hline 1 & Medis & \\
& Dokter Umum & 16 \\
& Dokter Spesialis & 39 \\
& Dokter Gigi & 3 \\
& Perawat & 179 \\
& Bidan & 29 \\
Jumlah & 266 \\
Penunjang Medis & \\
Farmasi & 14 \\
Kesehatan Lingkungan & 2 \\
Tenaga Gizi & 4 \\
Analisis Kesehatan & 14 \\
Radiologi & 11 \\
Rekam Medik & 5 \\
Para Medis & 32 \\
Jumlah & 65 \\
Non Medis & 169 \\
Tenaga Administrasi &
\end{tabular}




\begin{tabular}{lr}
\hline Jumlah & 500 \\
\hline Sumber : SDI RS PKU Muhammadiyah Gombong
\end{tabular}

RS PKU Muhammadiyah Gombong mempunyai jenis beberapa fasilitas pelayanan : instalasi rawat jalan ( 21 poliklinik ), Instalasi rawat inap ( 13 ruang perawatan ), Instalasi ruang intensif ( ICU, PICU, NICU ), Instalasi Bedah Sentral, Instalasi Gawat Darurat, Instalasi Radiologi, Instalasi Haemodialisa, Instalasi Gizi, Instalasi Maternal Perinatal.Kapasitas tempat tidur di RS PKU Muhammadiyah Gombong secara keseluruhan terbagi dalam beberapa ruang perawatan. Secara rinci jumlah tempat tidur dapat dilihat pada tabel 4.2 berikut :

Tabel 2. Jenis Ruang Rawat Inap

\begin{tabular}{clr}
\hline No & \multicolumn{1}{c}{ Kelas } & Jumlah Bed \\
\hline 1 & VIP & 14 \\
2 & Utama & 12 \\
3 & Kelas 1 & 4 \\
4 & Kelas 2 & 18 \\
5 & Kelas 3 & 32 \\
6 & Jamkesmas & 47 \\
7 & ICU, PICU, NICU & 9 \\
\hline & Jumlah & 136 \\
\hline
\end{tabular}

$\overline{\text { Sumber : Data Rumah Tangga RS PKU Muhammadiyah }}$

Gambaran umum ruang rawat inap Inayah yaitu RS PKU Muhammadiyah Gombong mempunyai dua jenis pelayanan perawatan yaitu rawat inap dan rawat jalan. Ruang rawat inap inayah merupakan ruang rawat inap kelas III, Ruang Inayah memiliki 32 tempat tidur dengan luas $616 \mathrm{~m}^{2}$.Ruang rawat inap Inayah memiliki kapasitas bed yang tinggi, sehingga di ruang inayah terdapat banyak pasien dan pengunjung. Jumlah pasien dan pengunjung yang banyak serta aktivitas pengunjung dan pasien di ruang rawat inap Inayah dapat mengakibatkan tingkat kebersihan ruang rawat inap Inayah menurun.

Tabel 3. Jumlah Pasien Ruang Rawat Inap Inayah

\begin{tabular}{clr}
\hline No & \multicolumn{1}{c}{ Bulan } & Jumlah Pasien \\
\hline 1 & Januari & 274 \\
2 & Februari & 210 \\
3 & Maret & 252 \\
4 & April & 217 \\
5 & Mei & 208 \\
\hline & Jumlah & 1161 \\
\hline
\end{tabular}

Sumber : Data Rekam Medis RS PKU Muhammadiyah Gombong tahun 2017

Rumah Sakit PKU Muhammadiyah Gombong mempunyai dua jenis pelayanan perawatan yaitu rawat inap dan rawat jalan. Ruang rawat inap Barokah merupakan merupakan ruang rawat inap untuk pasien yang mempunyai Jamkesmas, ruang Barokah memiliki 47 tempat tidur dengan luas $420 \mathrm{~m}^{2}$.Ruang Barokah memiliki kapasitas bed yang tinggi, sehingga di ruang Barokah terdapat banyak pasien dan pengunjung. Jumlah pasien dan pengunjung yang banyak dapat mengakibatkan tingkat kebersihan ruang rawat inap Barokah menurun.

Tabel 4. Jumlah Pasien Ruang Rawat Inap Barokah

\begin{tabular}{clr}
\hline No & \multicolumn{1}{c}{ Bulan } & Jumlah Pasien \\
\hline 1 & Januari & 296 \\
2 & Februari & 263 \\
3 & Maret & 310 \\
4 & April & 247 \\
5 & Mei & 264 \\
\hline & Jumlah & 1380 \\
\hline
\end{tabular}

Sumber : Data Rekam Medis RS PKU Muhammadiyah Gombong tahun 2017

Hasil evaluasi pelaksanaan basic housekeeping pada ruang rawat inap Inayah yaitu : Alat dan bahan yang digunakan untuk kegiatan dusting yaitu : cleaning cloth kuning untuk infeksius, cleaning cloth biru untuk non infeksius, bottle sprayer, chemical century dan netral. Petugas melakukan dusting dengan cara melipat cleaning cloth seukuran telapak tangan dan menyemprot dengan chemical. Petugas mengelap dari bagian dalam ke bagian luar, selanjutnya petugas melipat kembali cleaning cloth supaya mendapatkan permukaan kain yang bersih. Pelaksanaan dusting pada ruang rawat inap Inayah sudah sesuai dengan standard operational procedure, namun pelaksanaan dusting pada handle pintu belum dilakukan dilakukan dengan rutin yaitu pada setiap shift.Wahana pemindahahsebaran mikrobe melalui udara yaitu tetesan air liur, sekresi pernafasan lain, debu tercemar, dan formit atau benda mati yang tercemar oleh patogen dan membantu penyebarannya ( Lud Waluyo, 2007, h.312 ). Salah satu formit yang ada di ruang rawat inap Inayah yaitu handle pintu. Apabila handle pintu tidak dilaksanakan dusting secara rutin, maka virus Variola, Varisela-zoster, Rubeola, Rubela, Gondong, Polio. Virus tersebut memberikan peluang terjadinya penyakit cacar, campak, campak jerman, gondong dan polio.Sebaiknya pelaksanaan dusting pada handle pintu di ruang rawat inap Inayah dilakukan secara rutin yaitu pada setiap shift. Pelaksanaan dusting pada handle pintu dengan rutin dapat membunuh virus yang ada pada handle pintu. Pelaksanaan basic housekeeping pada ruang rawat inap Barokah yaitu : Alat dan bahan yang digunakan untuk kegiatan dusting yaitu : cleaning cloth kuning untuk infeksius, cleaning cloth biru untuk non infeksius, bottle sprayer, chemical century dan netral. Petugas melakukan dusting dengan cara melipat cleaning cloth seukuran telapak tangan dan menyemprot dengan chemical. Petugas mengelap dari 
bagian dalam ke bagian luar, selanjutnya petugas melipat kembali cleaning cloth supaya mendapatkan permukaan kain yang bersih. Pelaksanaan dusting pada ruang rawat inap Barokah sudah sesuai dengan standard operational procedure, namun pelaksanaan dusting pada handle pintu belum dilakukan dilakukan dengan rutin yaitu pada setiap shift. Petugas tidak melakukan kegiatan dusting pada handle pintu secara rutin. Wahana pemindahahsebaran mikrobe melalui udara yaitu tetesan air liur, sekresi pernafasan lain, debu tercemar, dan formit atau benda mati yang tercemar oleh patogen dan membantu penyebarannya ( Lud Waluyo, 2007, h.312 ). Salah satu formit yang ada di ruang rawat inap Barokah yaitu handlepintu. Apabila handle pintu tidak dilaksanakan dusting secara rutin, maka bakteri Corynebacterium diptheriae, Streptococcus pyogenes, Mycobacteriumtubercolusis,Streptococcus pneumoniae, Neisseria meningitidis, Bordetella pertussis dapat hidup dan berkembangbiak pada handle pintu. Bakteri tersebut memberikan peluang terjadinya penyakit difteri, faringitis, tuberkulosis, pneumonia, meningitis dan pertusis.Berdasarkan pemeriksaan usap pada handle pintu ruang observasi Barokah, didapatkan hasil yang tidak sesuai dengan baku mutu. Sebaiknya pelaksanaan dusting pada handle pintu dilakukan secara rutin yaitu pada setiap shift, supaya handle pintu tidak menjadi tempat perkembangbiakan bakteri.Alat dan bahan yang digunakan untuk kegiatan dry mopping dengan lobby dusterdi uang rawat inap Inayahyaitu :lobby duster, dustpan, nyloon broom dan garbage bin. Pelaksanaan dry mopping dengan lobby duster pada ruang rawat inap Inayah dilakukan dengan cara menggerakan lobby duster dari bagian dalam ke bagian yang dekat pintu dengan gerakan mundur. Langkah kedua yaitu, kotoran dan debu dikumpulkan di depan pintu untuk selanjutnya dimasukkan ke dalam dustpan dengan menggunakan nylon broom.Pelaksanaan dry mopping dengan lobby duster pada ruang rawat inap Inayah sudah sesuai dengan standard operational procedure. Sebaiknya pelaksanaan dry mopping dengan lobby duster di ruang rawat inap Inayah dipertahankan sesuai dengan standard operasional procedure. Alat dan bahan yang digunakan untuk kegiatan dry mopping dengan lobby dusterdi ruang rawat inap Barokah yaitu : lobby duster, dustpan, nyloon broom dan garbage bin. Pelaksanaan dry mopping dengan lobby duster pada ruang rawat inap Barokah dilakukan dengan cara menggerakan lobby duster dari bagian dalam ke bagian yang dekat pintu dengan gerakan mundur. Langkah kedua yaitu, kotoran dan debu dikumpulkan di depan pintu untuk selanjutnya dimasukkan ke dalam dustpan dengan menggunakan nylon broom.Pelaksanaan dry mopping dengan lobby duster pada ruang Barokah oleh petugas telah menggunakan lobby duster dengan gerakan mundur dari bagian dalam ke arah luar. Debu dan kotoran kecil yang telah terkumpul diangkat ke dalam dustpan dengan menggunakan nylon broom.Pada salah satu ruang kamar rawat inap Barokah, petugas menggunakan nylon broom untuk melaksanakan kegiatan dry mopping. Hal tersebut mengakibatkan debu dan kotoran kecil yang ada di ruang kamar pasien tidak terangkat secara keseluruhan, karena bahan lobby duster yang terbuat dari kainlebih efektif untuk mengangkat debu dan kotoran kecil.Sebaiknya petugas melakukan dry mopping menggunakan lobby duster, supaya debu dan kotoran kecil dapat terangkat secara keseluruhan. Alat dan bahan yang digunakan untuk kegiatan damp moppingdengan kentucky mopdi ruang rawat inap Inayah yaitu : kain mop, bucket, warning sign dan chemical century. Petugas melakukan damp mopping pertama kali di ruang rawat jaga perawat dan selanjutnya di ruang kamar pasien.Langkah pertama damp mopping yaitu, memasukan air dan chemical ke dalam bucket dengan perbandingan 1:5.Langkah kedua, kain mop dicelupkan ke dalam bucket dan selanjutnya kain mop diperas sampai dalam kondisi lembab.Selanjutnya, petugas mengepel dari bagian dalam ke bagian luar dengan gerakan mundur.Pelaksanaan damp mopping dengan kentucky mop di ruang rawat inap inayahtelah menggunakan kain mop yang berbeda untuk ruang jaga perawat dan ruang kamar pasien, yaitu warna biru untuk ruang jaga perawat dan warna kuning untuk ruang kamar pasien.Petugas tidak mengganti air dan chemical yang berada dalam bucket.Apabila larutan yang sama dipakai seharian, maka dapat mengakibatkan pencemaran oleh mikroba yang lebih parah dibandingkan dengan sebelum dibersihkan ( Michael J.Pelzar,Jr., dan E.C.S. CHAN, 1988, h.752 ). Berdasarkan hasil usap pada lantai ruang rawat inap Inayah, didapatkan hasil yang tidak memenuhi baku mutu. Sebaiknya, jika mop sudah kotor jangan terus dipakai melainkan harus dibersihkan, dibilas dan diperas lagi. Jika air sudah kotor maka air tersebut harus diganti ( Bagyono,2009, h.128 ).Petugas yang tidak memasang warning sign pada area kerja dapat mengakibatkan terjadinya kecelakaan kerja.Sebaiknya, petugas memasang penanda dan isyarat keselamatan kerja untuk mencegah terjadinya kecelakaan kerja pada ruang rawat inap Inayah. Penggunaan papan penanda keselamatan yang benar di tempat kerja dapat menggalakan instruksi - instruksi dan aturan - aturan keselamatan kerja dan dapat memberikan informasi atas resiko dan tindakan pencegahan yang harus diambil ( John Ridley, 2008, h.100 ).Alat dan bahan yang digunakan untuk kegiatan damp mopping yaitu : kain mop, bucket, warning sign dan chemical century. Petugas melakukan damp mopping pertama kali di ruang rawat jaga perawat dan selanjutnya di ruang kamar pasien.Langkah pertama damp mopping yaitu, memasukan air dan chemical ke dalam bucket dengan perbandingan 1:5.Langkah kedua, kain mop dicelupkan ke dalam bucket dan selanjutnya kain mop diperas sampai dalam kondisi lembab. 
Selanjutnya, petugas mengepel dari bagian dalam ke bagian luar dengan gerakan mundur.Pada saat berpindah dari ruang kamar pasien ke kamar pasien yang lainnya, petugas tidak mengganti air dan chemical yang ada di dalam bucket. Petugas tidak memasang warning sign pada saat pelaksanaan damp mopping pada ruang kamar pasien.Pelaksanaan damp mopping dengan kentucky mop di ruang rawat inap Barokah telah menggunakan kain mop yang berbeda untuk ruang jaga perawat dan ruang kamar pasien. Warna biru untuk ruang jaga perawat dan warna kuning untuk ruang kamar pasien.Petugas tidak mengganti air dan chemical yang berada dalam bucket.Apabila larutan yang sama dipakai seharian, maka dapat mengakibatkan pencemaran oleh mikroba yang lebih parah dibandingkan dengan sebelum dibersihkan ( Michael J.Pelzar,Jr., dan E.C.S. CHAN, 1988, h.752 ). Sebaiknya, jika mop sudah kotor jangan terus dipakai melainkan harus dibersihkan, dibilas dan diperas lagi. Jika air sudah kotor maka air tersebut harus diganti( Bagyono,2009, h.128 ). Petugas tidak memasang warning sign pada area kerja dapat mengakibatkan terjadinya kecelakaan kerja.Sebaiknya, petugas memasang penanda dan isyarat keselamatan kerja untuk mencegah terjadinya kecelakaan kerja pada ruang rawat inap Barokah. Penggunaan papan penanda keselamatan yang benar di tempat kerja dapat menggalakan instruksi - instruksi dan aturan - aturan keselamatan kerja dan dapat memberikan informasi atas resiko dan tindakan pencegahan yang harus diambil ( John Ridley, 2008, h.100 ).Alat dan bahan yang digunakan untuk kegiatan glass cleaningdi ruang rawat inap Inayah yaitu :bucket, window washer, window squeegee, floor cloth dan chemical glass and surface cleaner. Petugas cleaning service melakukan kegiatan glass cleaning, dengan langkah pertama yaitu, memasang warning sign pada area kerja dan terlihat umum.Langkah kedua, yaitu petugas membersihkan permukaan kaca dengan menggunakan window washer yang dicelupkan ke dalam bucket yang berisi air dan chemical.Langkah ketiga yaitu, window washer diperas sampai dalam kondisi lembab dan selanjutnya permukaan kaca dilap dan dibasahi dengan menggunakan window washer.Langkah ke empat yaitu, permukaan kaca yang basah dikeringkan dengan meggunakan window squeegee.Pelaksanaan glass cleaning tidak dilakukan secara rutin pada ruang rawat inap Inayah, hal tersebut dapat mengakibatkan terakumulasinya bakteri pada kaca yang ada pada ruang rawat inap Inayah dan Barokah.Akibat dari terakumulasi bakteri di kaca maka dapat mengakibatkan terjadinya infeksi nosokomial.Sumber Infeksi nosokomial terdapat dua jenis yaitu infeksi endogenus dan infeksi eksogenus.Infeksi eksogenus merupakan suatu penyakit yang disebabkan oleh kuman dari luar tubuh.Sumber luar meliputi semua reservoir yang secara potensial mengandung penyebab penyakit. Karena tujuannya yang khusus, maka rumah sakit merupakan tempat berkumpunya pasien yang menderita infeksi yang sudah maupun yang belum di diagnosis, seperti misalnya penderita tuberkolosis yang mungkin pembawa patogen lain ( Michael J.Pelzar,Jr., dan E.C.S. CHAN, 1988, h.737 ).Pada ruang Inayahterdapat ruang Isolasi danObservasi yang terdapat pasien yang mempunyai ketahanan tubuh yang lemah akibat dari luka berat, penyakit, atau operasi, maka patogen dapat berkembangbiak dan menyebabkan sakit.( Michael J.Pelzar,Jr., dan E.C.S. CHAN, 1988, h.737 ).Sebaiknya, pelaksanaan glass cleaning dilakukan secara rutin, supaya debu dan kotoran tidak terakumulasi di kaca dan menyebabkan terjadinya infeksi nosokomial.Pelaksanaan glass cleaning di ruang rawat inap Barokah dilakukan apabila kaca kotor.Glass cleaning bukan merupakan kegiatan harian yang dilakukan oleh petugas kebersihan di ruang rawat inap Barokah.Alat dan bahan yang digunakan untuk kegiatan glass cleaning yaitu :bucket, window washer, window squeegee, floor cloth dan chemical glass and surface cleaner. Petugas cleaning service melakukan kegiatan glass cleaning, dengan langkah pertama yaitu, memasang warning sign pada area kerja dan terlihat umum.Langkah kedua, yaitu petugas membersihkan permukaan kaca dengan menggunakan window washer yang dicelupkan ke dalam bucket yang berisi air dan chemical.Langkah ketiga yaitu, window washer diperas sampai dalam kondisi lembab dan selanjutnya permukaan kaca dilap dan dibasahi dengan menggunakan window washer.Langkah ke empat yaitu, permukaan kaca yang basah dikeringkan dengan meggunakan window squeegee.Pelaksanaan glass cleaning tidak dilakukan secara rutin pada ruang rawat inap Barokah, hal tersebut dapat mengakibatkan terakumulasinya bakteri pada kaca yang ada pada ruang rawat inap Barokah.Akibat dari terakumulasi bakteri di kaca maka dapat mengakibatkan terjadinya infeksi nosokomial.Sumber Infeksi nosokomial terdapat dua jenis yaitu infeksi endogenus dan infeksi eksogenus.Infeksi eksogenus merupakan suatu penyakit yang disebabkan oleh kuman dari luar tubuh.Sumber luar meliputi semua reservoir yang secara potensial mengandung penyebab penyakit. Karena tujuannya yang khusus, maka rumah sakit merupakan tempat berkumpunya pasien yang menderita infeksi yang sudah maupun yang belum di diagnosis, seperti misalnya penderita tuberkolosis yang mungkin pembawa patogen lain ( Michael J.Pelzar,Jr., dan E.C.S. CHAN, 1988, h.737 ).Pada ruang Barokah terdapat ruang Observasi yang terdapat pasien yang mempunyai ketahanan tubuh yang lemah akibat dari luka berat, penyakit, atau operasi, maka patogen dapat berkembangbiak dan menyebabkan sakit.( Michael J.Pelzar,Jr., dan E.C.S. CHAN, 1988, h.737 ). Sebaiknya, pelaksanaan glass cleaning dilakukan secara rutin, supaya debu dan 
kotoran tidak terakumulasi di kaca dan menyebabkan terjadinya infeksi nosokomial

Alat yang digunakan untuk kegiatan toilet cleaningInayahyaitu :bucket, nylon broom, toilet bowl brush, rubber hand gloves, bottle sprayer, warning sign, rug ball. Bahan yang digunakan yaitu chemical century dan odor control.Petugas melaksanakan kegiatan toilet cleaning dengan langkah pertama yaitu, menggunakan sarung tangan dan selanjutnya petugas memasangwarning sign.Langkah kedua, petugas membersihkan langit - langit dari debu dan sarang laba - laba dengan menggunakan rug ball. Langkah ketiga, petugas menyemprotkan cairan Century ke dalam closet kemudian didiamkan tiga sampai lima menit. Langkah ke empat, petugas menggosok dinding hinggga bersih, kemudian petugas kembali lagi ke closet dan menggosoknya dengan menggunakan toilet bowl brush. Langkah ke lima yaitu, petugas membersihkan pemukaan lantai dari kotoran dan noda dan selanjutnya menyemprotkan chemical berupa odor control untuk menghilangkan bau di dalam toilet.Pada saat pelaksanaan toilet cleaning pada closet menggunakan chemical, petugas membiarkan dalam waktu kurang dari lima menit. Hal tersebut menyebabkan chemical tidak bekerja secara optimal dalam membunuh bakteri yang ada pada closet sehingga toilet bau.Sebaiknya, pada saat membersihkan toilet dengan caraspray toilet bowl dengan chemical, kemudian tunggu kurang lebih limamenit supaya chemical bereaksi dengan kotoran ( Bagyono, 2009, h. 133 ).Alat yang digunakan untuk kegiatan toilet cleaningBarokahyaitu :bucket, nylon broom, toilet bowl brush, rubber hand gloves, bottle sprayer, warning sign, rug ball. Bahan yang digunakan yaitu chemical century dan odor control.Petugas melaksanakan kegiatan toilet cleaning dengan langkah pertama yaitu, menggunakan sarung tangan dan selanjutnya petugas memasangwarning sign.Langkah kedua, petugas membersihkan langit - langit dari debu dan sarang laba - laba dengan menggunakan rug ball. Langkah ketiga, petugas menyemprotkan cairan Century ke dalam closet kemudian didiamkan tiga sampai lima menit. Langkah ke empat, petugas menggosok dinding hinggga bersih, kemudian petugas kembali lagi ke closet dan menggosoknya dengan menggunakan toilet bowl brush. Langkah ke lima yaitu, petugas membersihkan pemukaan lantai dari kotoran dan noda dan selanjutnya menyemprotkan chemical berupa odor control untuk menghilangkan bau di dalam toilet.Pada saat pelaksanaan toilet cleaning pada closet menggunakan chemical, petugas membiarkan dalam waktu kurang dari lima menit. Hal tersebut menyebabkan chemical tidak bekerja secara optimal dalam membunuh bakteri yang ada pada closet sehingga toilet bau.Sebaiknya, pada saat membersihkan toilet dengan caraspray toilet bowl dengan chemical, kemudian tunggu kurang lebih limamenit supaya chemical bereaksi dengan kotoran (
Bagyono, 2009, h. 133 ).Pelaksanaan kegiatan wet vacuuming tidak dilakukan pada ruang rawat inap Inayah dan Barokah, karena kegiatan wetvacuuming hanya dilakukan pada ruangan yang terdapat karpet, seperti ruang direksi yang ada di RS PKU Muhammadiyah Gombong.Pelaksanaan kegiatandry vacuuming tidak dilakukan pada ruang rawat inap Inayah dan Barokah, karena kegiatan wetvacuuming hanya dilakukan pada ruangan yang terdapat karpet, seperti ruang direksi yang ada di RS PKU Muhammadiyah Gombong.Pelaksanaan kegiatan scrubbing tidak dilakukan di ruang rawat inap Inayah karena kotoran dan noda yang ada di ruang rawat inap Inayah dan Barokah dapat terangkat melalui kegiatan dry mopping dengan lobby duster dan damp mopping dengan kentucky mop.Kegiatan stripping lantai vynil tidak dilakukan di ruang rawat inap Inayah dan Barokah, karena kegiatan tersebut hanya dilakukan pada permukaan lantai Vynil, ruangan RS PKU Muhammadiyah Gombong yang memiliki permukaalantai Vynil yaitu ruang ICU, IGD, IBS dan Haemodialisa.Kegiatan coating lantai vynil tidak dilakukan di ruang rawat inap Inayah dan Barokah, karena kegiatan tersebut hanya dilakukan pada permukaan lantai Vynil, ruangan RS PKU Muhammadiyah Gombong yang memiliki permukaalantai Vynil yaitu ruang ICU, IGD, IBS dan Haemodialisa. Berdasarkan hasil sampel usap pada ruang rawat inap Inayah dan Barokah terdapat dua sampel usap yang tidak memenuhi baku mutumenurut Kepmenkes RI No.1204/Menkes/SK/X/2004 tentang Persyaratan Kesehatan Lingkungan Rumah Sakit. Dua sampel yang tidak memenuhi baku mutu yaitu handle pintu dengan hasil $19 \mathrm{CFU} / \mathrm{cm}^{2}$ pada ruang observasi ruang rawat inap Barokah.Menurut peneliti dan berdasarkan observasi pelaksanaan dusting di ruang rawat inap Barokah, pertama disebabkan karena pelaksanaan dusting yang tidak rutin dilakukan pada ruang rawat inap Barokah.Kedua, karena perilaku pengunjungdan pasien yang tidak cuci tangan menggunakan sabun atau hand sanitizer setelah dari toilet. Sehingga, pada saat memegang handle pintu, kuman berpindah dari tangan ke handle pintu.Sebaiknya pelaksanaan dusting pada handle pintu di ruang rawat inap Inayah dan Barokah dilakukan secara rutin yaitu pada setiap shift. Pelaksanaan dusting pada handle pintu dengan rutin dapat membunuh bakteri yang ada pada handle pintu. Sebaiknya pasien dan pengunjung cuci tangan pakai sabun atau menggunakan hand sanitizer setelah keluar dari toilet.Menurut hasil penelitian Indah Rakhmi Pafitri (2016) menujukkan rata-rata angka kuman pada handle pintu ruang kamar enam sebesar $1.632,5 \mathrm{kol} / \mathrm{cm}^{2}$.Peneliti menyarankan supaya pihak rumah sakit melakukan pembersihan terhadap handle pintu menggunakan desinfektan dan meperhatikan kondisi lingkungan supaya tetap bersih.Sampel ke dua 


\begin{tabular}{|c|c|c|}
\hline Shift & $\begin{array}{c}\text { Pelaksanaan basic } \\
\text { housekeeping }\end{array}$ & Alat dan Bahan \\
\hline $\begin{array}{ll}\text { 1. } & 07.00 \\
\text { 2. } & 14.00 \\
\text { 3. } 22.00\end{array}$ & Dusting & $\begin{array}{lr}\text { Lap } & \text { handuk } \\
\text { biru(non ifeksius), } \\
\text { lap handuk } \\
\text { kuning kuning, } \\
\text { (infeksius), bottle } \\
\text { sprayer, bucket, } \\
\text { chemical century } \\
\text { dan netral. }\end{array}$ \\
\hline $\begin{array}{ll}\text { 1. } & 07.30 \\
\text { 2. } & 14.30 \\
\text { 3. } & 22.30\end{array}$ & $\begin{array}{l}\text { Dry mopping } \\
\text { dengan lobby duster }\end{array}$ & $\begin{array}{lr}\text { Lobby duster, } & \\
\text { Dustpan, nylon } \\
\text { broom, garbage } \\
\text { bin, warning sign. }\end{array}$ \\
\hline $\begin{array}{ll}\text { 1. } & 07.30 \\
\text { 2. } & 14.30 \\
\text { 3. } & 22.30\end{array}$ & $\begin{array}{l}\text { Damp mopping } \\
\text { dengan kentucky } \\
\text { mop }\end{array}$ & $\begin{array}{l}\text { Double bucket, } \\
\text { kentucky } \\
\text { mop/mop , set } \\
\text { biru (non } \\
\text { infeksius),kentuck } \\
\text { y mop/mop set } \\
\text { kuning(infeksius), } \\
\text { warning sign, } \\
\text { chemical century. }\end{array}$ \\
\hline $\begin{array}{ll}\text { 1. } & 09.00 \\
\text { 2. } & 16.00 \\
\text { 3. } & 24.00\end{array}$ & Toilet cleaning & $\begin{array}{lr}\text { Abrasive } & \text { pad, } \\
\text { bottle sprayer, } \\
\text { rug ball, toilet } \\
\text { bowl } & \text { brush, } \\
\text { warning sign, } \\
\text { chemical century } \\
\text { dan } \\
\text { conntrol. odor }\end{array}$ \\
\hline 16.00 & Glass cleaning & $\begin{array}{l}\text { Window washer } \\
\text {,windowsqueegee, } \\
\text { bucket,warningsig } \\
n \text {, chemical glass } \\
\text { and } \\
\text { surfacecleaner. }\end{array}$ \\
\hline
\end{tabular}

yang tidak memenuhi baku mutu yaitu sampel pada lantai Inayah kamar 21 dengan hasil 31 $\mathrm{CFU} / \mathrm{cm}^{2}$.Menurut peneliti dan berdasarkan observasi pelaksanaan damp mopping dengan kentucky mop di ruang rawat inap Inayah, pertama disebabkan karena Petugas tidak mengganti air dan chemical yang berada dalam bucket. Kedua, disebabkan karena perilaku pengunjung yang beraktivitas pada lantai yang masih basah setelah kegiatan damp mopping.Apabila larutan yang sama dipakai seharian,maka dapat mengakibatkan pencemaran oleh mikroba yang lebih parah dibandingkan dengan sebelum dibersihkan( Michael J.Pelzar,Jr., dan E.C.S. CHAN, 1988, h.752 ). Sebaiknya, jika mop sudah kotor jangan terus dipakai melainkan harus dibersihkan, dibilas dan diperas lagi. Jika air sudah kotor maka air tersebut harus diganti( Bagyono,2009, h.128 ).
Tabel 5. Waktu pelaksanaan basic housekeeping

\section{Kesimpulan}

BerdasarkanSOP pelaksanaan basic housekeeping di RS PKU Muhammadiyah Gombong, pelaksanaan dusting pada ruang rawat inap Inayah dan dan Barokah sudah sesuai dengan SOP. Pelaksanaan dusting pada handle pintu ruang rawat inap Inayah dan Barokah tidak dilakukan secara rutin, sehingga pada pemeriksaan usap handle pintu ruang Observasi Barokah hasilnya tidak sesuai dengan baku mutu yaitu $19 \mathrm{CFU} / \mathrm{cm}^{2}$. Pelaksanaan kegiatandry mopping dengan lobby duster pada ruang rawat inap Inayah sudah sesuai dengan standard operational procedure.Pada salah satu kamar ruang rawat inap Barokah, petugas tidak menggunakan lobby duster untuk melaksanakan kegiatan dry mopping, namun menggunakan nylon broom.Pelaksanaan kegiatan damp mopping dengan kentucky mop pada ruang rawat inap Inayah ada yang belum sesuai dengan standard operational procedure. Petugas tidak memasang warning sign pada saat pelaksanaan kegiatan damp mopping dengan kentucky mop dan petugas tidak mengganti air yang ada di dalam bucket. Pelaksanaan kegiatan damp mopping dengan kentucky mop pada ruang rawat inap Barokah ada yang belum sesuai dengan standard operational procedure. Petugas tidak memasang warning sign pada saat pelaksanaan kegiatan damp mopping dengan kentucky mop dan petugas tidak mengganti air yang ada di dalam bucket, Sehingga terdapat sampel usap pada lantai yang tidak sesuai dengan baku mutu yaitu 31 $\mathrm{CFU} / \mathrm{cm}^{2}$.Pelaksanaan kegiatan glass cleaning pada ruang rawat inap Inayah sudah sesuai dengan standard operational procedure. Namun, pelaksanaan glass cleaning tidak dilakukan secara rutin, sehingga pada saat pelaksanaan evaluasi ditemukan noda pada kaca.Pelaksanaan kegiatan glass cleaning pada ruang rawat inap Barokah sudah sesuai dengan standard operational procedure. Namun, pelaksanaan glass cleaning tidak dilakukan secara rutin, sehingga pada saat pelaksanaan evaluasi ditemukan noda pada kaca. Pelaksanaan toilet cleaning pada ruang rawat inap Inayah ada yang belum sesuai dengan standard operational procedure.Pelaksanaan toilet cleaning pada ruang rawat inap Barokah ada yang belum sesuai dengan standard operational procedure. Petugas membiarkan chemical pada closet dalam waktu kurang dari lima menit. Pada ruang rawat inap Inayah dan tidak dilaksanakan kegiatan wet vacuuming. Pelaksanaan wet vacuuming hanya dilakukan pada ruangan pada rumah sakit yang terdapat karpet, seperti ruang direksi.Pada ruang rawat inap Barokah dan tidak dilaksanakan kegiatan wet vacuuming. Pelaksanaan wet vacuuming hanya dilakukan pada ruangan pada rumah sakit yang terdapat karpet, seperti ruang direksi.Pada ruang rawat 
inap Inayah, tidak dilaksanakan kegiatan dry vacuuming.Pelaksanaan dry vacuuming hanya dilakukan pada ruangan pada rumah sakit yang terdapat karpet, seperti ruang direksi.Pada ruang rawat inap Barokah, tidak dilaksanakan kegiatan dry vacuuming.Pelaksanaan dry vacuuming hanya dilakukan pada ruangan pada rumah sakit yang terdapat karpet, seperti ruang direksi.Pada ruang rawat inap Inayah, tidak dilaksanakan kegiatan scrubbing.Hal tersebut dikarenakan, noda dan kotoran pada lantai dapat terangkat melalui kegiatan dry mopping dengan lobby duster dan damp mopping dengan kentucky mop. Pada ruang rawat inap Barokah, tidak dilaksanakan kegiatan scrubbing. Hal tersebut dikarenakan, noda dan kotoran pada lantai dapat terangkat melalui kegiatan $d r y$ mopping dengan lobby duster dan damp mopping dengan kentucky mop.Pada ruang rawat inap Inayah tidak dilaksanakan kegiatan stripping lantai vynil.Pelaksanaan stripping lantai vynil hanya dilakukan pada permukaan lantai vynil, seperti pada ruang ICU, IBS, IGD dan Haemodialisa. Pada ruang rawat inap Barokah tidak dilaksanakan kegiatan stripping lantai vynil. Pelaksanaan stripping lantai vynil hanya dilakukan pada permukaan lantai vynil, seperti pada ruang ICU, IBS, IGD dan Haemodialisa.Pada ruang rawat inap Inayah tidak dilaksanakan kegiatan coating lantai vynil.Pelaksanaan coating lantai vynil hanya dilakukan pada permukaan lantai vynil, seperti pada ruang ICU, IBS, IGD dan Haemodialisa.Pada ruang rawat inap Barokah tidak dilaksanakan kegiatan coating lantai vynil.Pelaksanaan coating lantai vynil hanya dilakukan pada permukaan lantai vynil, seperti pada ruang ICU, IBS, IGD dan Haemodialisa.

\section{Ucapan Terima Kasih}

Penyelesaian penulisan karya tulis ilmiah ini penyusun banyak mendapatkan bantuan baik materil maupun moril dari berbagai pihak, untuk itu penyusun mengucapkan terima kasih kepada:Bapak Sugiyanto, S.Pd.,M.App.Sc selaku Direktur Poltekkes Kemenkes Semarang, Bapak Asep Tata Gunawan, SKM.,M.Kes selaku Ketua Jurusan Kesehatan Lingkungan, Bapak Suparmin, SST.,M.Kes selaku Ketua Program Studi Diploma III Kesehatan Lingkungan, Bapak Marsum, BE.,S.Pd.,MHP selaku Pembimbing Akademik, Bapak Tri Cahyono, SKM.,M.Si selaku pembimbing karya tulis ilmiah yang telah memberikan bimbingan dan saran yang membangun untuk peneliti.Keluarga tercinta, Bapak dan Ibu serta Kakaku tersayang yang telah memberikan doa serta dukungan dalam proses pembuatan karya tulis ilmiah.Teman-teman dan sahabat tersayang yang selalu memberi motivasi dan semangat.Teman-teman dan sahabat tersayang yang selalu memberi motivasi dan semangat.Pihak KesehatanLingkungan, Petugas ISS dan Karyawan Rumah Sakit PKU Muhammadiyah Gombong yang telah membantu dalam proses pembuatan karya tulis ilmiah.Penulis menyadari bahwa di dalam menyelesaikan karya tulis ilmiah ini masih jauh dari sempurna. Oleh karena itu, penulis mengharapkan kritik dan saran yang membangun untuk kesempurnaan karya tulis ilmiah ini pada waktu yang akan datang. Harapan penulis semoga karya tulis ilmiah ini dapat berguna dan bermanfaat bagi penulis maupun bagi pembaca pada umumnya.

\section{Daftar Pustaka}

A World Of Service Manual Operational Book For PKU Muhammadiyah Hospital Gombong.

Aziz Alimul Hidayat, 2007, Metode Penelitian Kebidanan dan Teknik Analisis Data, Jakarta : Salemba Medika.

Bagyono, 2009, Manajemen Housekeeping Hotel.Bandung : Alfabeta.

Hasil Pemeriksaan Laboaratorium Kesehatan Daerah Kabupaten Kebumen tahun 2016.

Indah Rakhmi Pafitri, 2016, KTI Studi Angka Kuman pada Handle Pintu Bagian Ruang Perawatan Mawar Kelas III RSUD Prof.Dr.Margono Soekarjo Purwokerto, Purwokerto : Jurusan Kesehatan Lingkungan Poltekkes Kemenkes Semarang

J.Pelczar,Jr Michael \& E.C.S Chan, 2008, Dasar-dasar Mikrobiologi, Jakarta : Universitas Indonesia.

John Ridley, 2008, Kesehatan dan Keselamatan Kerja, Jakarta : Erlangga.

Keputusan Menteri Kesehatan Republik Indonesia Nomor : 1204/Menkes/SK/X/2004 tentang Kesehatan Lingkungan Rumah Sakit, Jakarta.

Laporan Kerja Praktikum Mikrobiologi Lingkungan tahun 2014.

Lud Waluyo, 2007, Mikrobiologi Umum, Malang : Universitas Muhammadiyah Malang.

Muhammad Fuad, 2014, KTI Studi Komparasi Angka Kuman Udara Pada Ruang Perawatan Kelas III di IRNA II RSUD Prof.Dr. Margono Soekarjo Purwokerto, Purwokerto : Jurusan Kesehatan Lingkungan Poltekkes Kemenkes Semarang.

Nugraheni Ratna, Suhartono, 2012, Infeksi Nosokomial di RSUD Setjonegoro Kabupaten Wonosobo.

Peraturan Menteri Kesehatan Republik Indonesia Nomor 340/Menkes/Per/III/2010 Tentang Klasifikasi Rumah Sakit, Jakarta.

Peraturan Menteri Kesehatan Republik Indonesia Nomor 56 tahun 2014 tentang Klasifikasi dan Perizinan Rumah Sakit, Jakarta.

Peraturan Pemerintah Republik Indonesia Nomor 66 Tahun 2014 Tentang Kesehatan Lingkungan, Jakarta.

Rumekso, 2004.Housekeeping Hotel. Yogyakarta, C.V Andi Offset. 
Standard Performance Of Area : Hospital, tahun 2016.

Suparlan, 2012, Pengantar Pengawasan HygieneSanitasi Tempat - Tempat Umum Wisata \& Usaha-Usaha Untuk Umum, Surabaya: Percetakan Duatujuh.

Tria Widiastuti, 2008, KTI Studi Komparasi Jumlah Kuman pada Lantai Sebelum dan Sesudah Pemberian Desinfektan di Ruang Perawatan Bangsal Anak Rumah Sakit Umum Daerah Brebes, Purwokerto : Jurusan Kesehatan Lingkungan Poltekkes Kemenkes Semarang.

Tri Cahyono, 2014, Pedoman Penulisan Proposal dan Karya Tulis Ilmiah, Purwokerto :Jurusan Kesehatan Lingkungan Poltekkes Kemenkes Semarang.
Undang-Undang Republik Indonesia Nomor 44 Tahun 2009 Tentang Rumah Sakit, Jakarta.

Undang-Undang Republik Indonesia Nomor 36 Tahun 2009 Tentang Kesehatan, Jakarta.

Yusda Dhani Kusuma, 2009, KTI Studi Angka Kuman Pada Lantai di Ruang Melati RSUD Prof.Dr.Margono Soekarjo Purwokerto, Purwokerto : Jurusan Kesehatan Lingkungan Poltekkes Kemenkes Semarang. 